\title{
Vertical Distribution and Standing Crop of Seaweeds, Seagrasses, Sea Urchins and the Spiny Top Shell Along the Coasts from Tappi to Fujishima, Tsugaru Peninsula, Aomori Prefecture
}

\author{
Masahiro Notoya* and Yusho Aruga* \\ (Received December 2, 1991)
}

\begin{abstract}
Standing crops of 9 species of macroalgae (Phaeophyta), 2 species of seagrasses, 4 species of sea urchins, and the spiny top shell was investigated at depths of $2,5,10,15$, and $20 \mathrm{~m}$ along 23 transects on the coasts from west of Tappi to Fujishima, Tsugaru Peninsula, Aomori Prefecture on August 2-6, 1985. Characteristic differences were observed in their vertical distributions between the Japan Sea coast and the Tsugaru Channel coast with Tappi Point as the border. The vertical distribution of standing crops of the spiny top shell and the sea urchin Strongylocentrotus nudus was quite similar to that of Ecklonia stolonifera and Laminaria japonica, respectively. These results suggest that the two species of seaweed, whether for food or habitat, are favored by sea animals.
\end{abstract}

The coasts of Aomori Prefecture in the northernmost part of Honshu, Japan, are influenced by the two oceanic currents of the Tsushima Warm Current from southern part of the Japan Sea and the Kurile Cold Current from northern part of the Pacific. ${ }^{1,2)}$ These two waters flow into the Tsugaru Channel. The warm water affects the coasts of Tsugaru Channel in summer, whereas the cold water affects the coasts in winter. Tappi Point and Shiriya Point are located respectively at the west and the east ends of Tsugaru Channel on the coasts of Aomori Prefecture (Fig. 1). Tappi Point divides the coastal area of Tsugaru Peninsula into two regions with different environmental conditions. The west coast of Tappi Point (the Japan Sea coast) is affected strongly by the warm water and the east coast of Tappi Point (the Tsugaru Channel coast) is affected moderately by both the warm and the cold waters.

There have been several reports on marine flora along the coasts of Aomori Prefecture. ${ }^{3-(y)}$ In these reports, it is described that several warm water species of seaweeds are found mainly along the Japan Sea coasts and both warm- and coldwater species occur mixed along the Tsugaru Channel coast. However, there have been few reports on the vertical distribution of subtidal standing crop of seaweeds except for some Laminariales species or macroalgae. ${ }^{a-12}$ )
We investigated the seaweed vegetation in reference mainly to the vertical distributions of standing crop of nine macroalgal species of Phaeophyta, two species of seagrasses and two groups of seaweed-eating benthos, sea urchins and the spiny top shell, along the coasts from west side of Tappi Point to Fujishima facing Tsugaru Channel and discussed the characteristics of vertical distributions of the species.

\section{Methods}

Investigations were carried out along 23 transects at intervals of about $500 \mathrm{~m}$ (Fig. 1) on August $2-6,1985$. Transects were laid from the coast to offshore and samples for the standing crop measurement were taken at depths of 2,5 , 10,15 , and $20 \mathrm{~m}$ in the subtidal zone where the substratum was composed mainly of rocks and large boulders. In some regions, the substratum was composed of rocks, large boulders and sand. At each depth, three quadrats of $50 \times 50 \mathrm{~cm}$ were placed for seaweeds and seagrasses and three quadrats of $100 \times 100 \mathrm{~cm}$ were placed for sea urchics and the spiny top shell. Organisms in the quadrats were collected by SCUBA diving, and the wet weight was determined for each species.

* Laboratory of Phycology, Tokyo University of Fisheries, Konan, Minato, Tokyo 108, Japan (能登谷 正浩, 有賀栯勝：東京水應大学藻類学研觉室). 


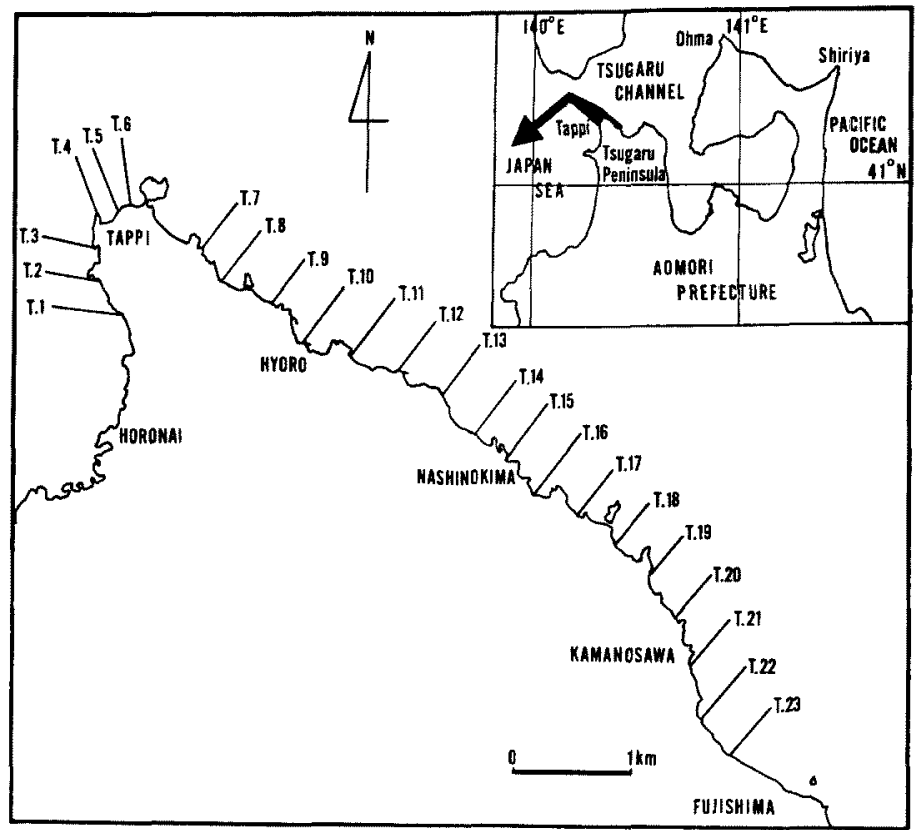

Fig. 1. Map showing the sites of investigation (T.1-23) in Tsugaru Peninsula, Aomori Prefecture.

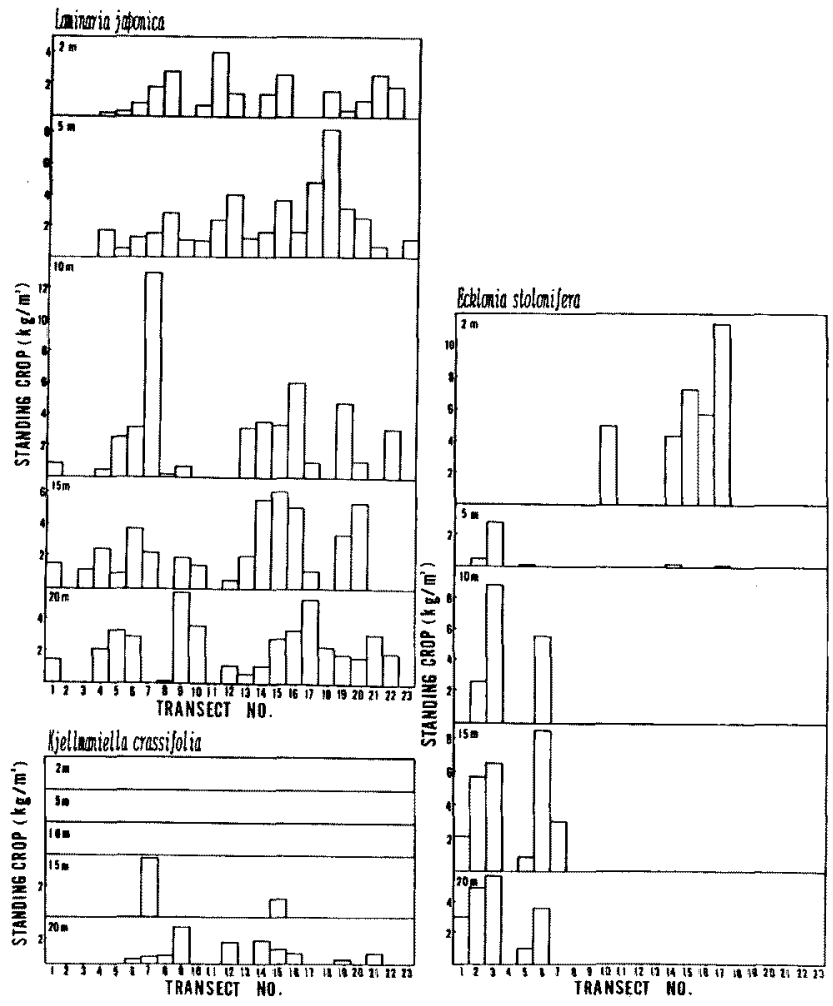

Fig. 2. Standing crops of Laminariales species at different depths. 


\section{Results}

Three species of Laminariales were obtained: Laminaria japonica Areschoug, Kjelmaniella crassifolia Miyabe, and Ecklonia stolonifera Okamura (Fig. 2).

L. japonica was mainly distributed at transects 4-22 on the Tsugaru Channel coast from shallow to deep water, except for transect 11. At transects 1-3 on the Japan Sea coast, this species was found only in deep water of $10-20 \mathrm{~m}$ with low standing crop. $K$. crassifolia was found only in deep water of 15 and $20 \mathrm{~m}$ at transects on the Tsugaru Channel coast. E. stolonifera was distributed from shallow to deep water of 5-20 m at transects on the Japan Sea coast, whereas only in shallow water of 2 and $5 \mathrm{~m}$ at some transects on the Tsugaru Channel coast. Thus, the vertical distribution of this species was quite characteristic, showing a sharp difference between the Japan Sea coast and the Tsugaru Channel coast.

Six sargassaceous species were found: Sargas- sum horneri (Turner) C. Agardh, S. confusum C. Agardh, S. micracanthum (Kützing) Endlicher, S. macrocarpum C. Agardh, S. siliquastrum (Mertens ex Turner) C. Agardh, and Myagropsis myagroides (Kützing) Fensholt (Fig. 3).

Distribution of $S$. macrocarpum was restricted mostly at transects on the Japan Sea cast with a high standing crop in water of 5-15 m. M. my agroides was observed with a relatively high standing crop from shallow to deep water at transects $1-3$, while mainly in shallow water of 2 and $5 \mathrm{~m}$ at transects $10-19 . S$. horneri was distributed in deep water of $10-20 \mathrm{~m}$ mainly at transects on the Tsugaru Channel coast. Although $S$. siliquastrum was found at almost all the transects and depths, the standing crop was relatively high in shallow water of 2 and $5 \mathrm{~m}$. Distrbutions of $S$. micracanthum and $S$. confusum were similar, being found in shallow to deep water mostly at transects on the Tsugaru Channel coast.

Two species of seagrasses were found: Zostera asiatica Miki and Phyllospadix iwatensis Makino
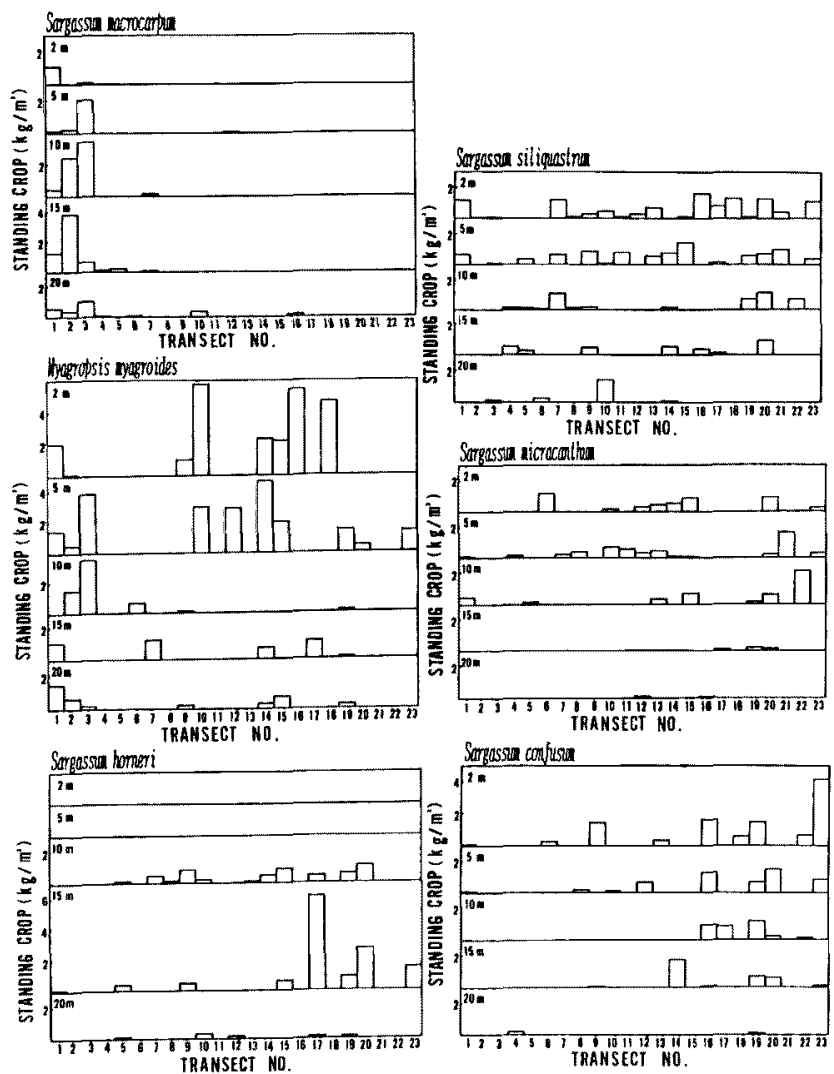

Fig. 3. Standing crops of sargassaceous species at different depths. 


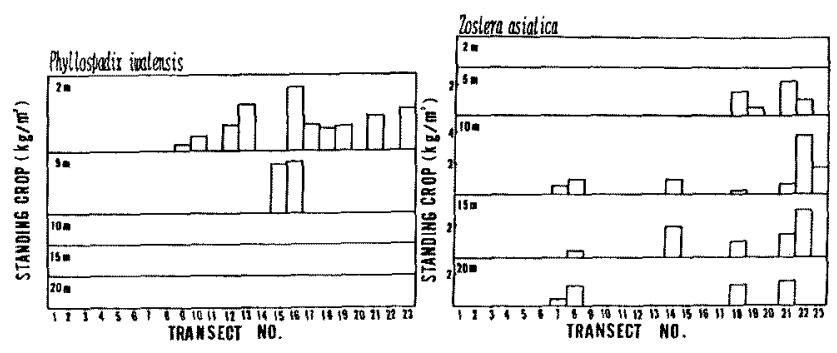

Fig. 4. Standing crops of seagrasses at different depths.

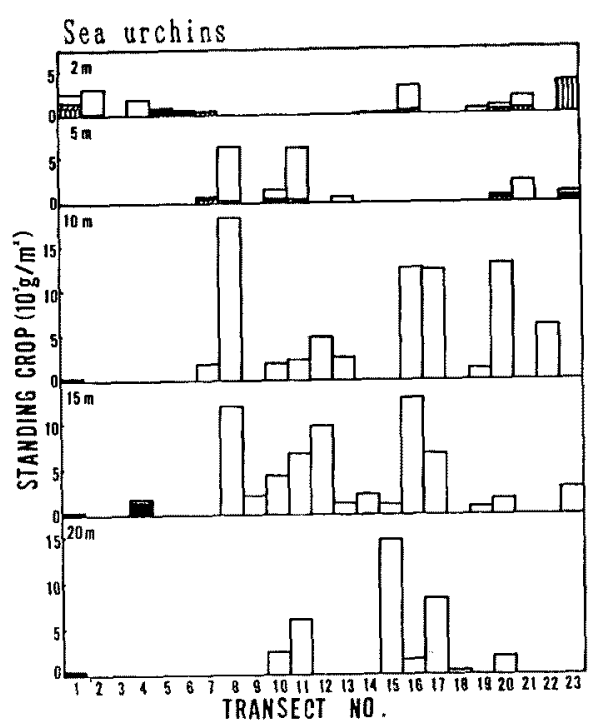

Fig. 5. Standing crops of sea urchins at different depths. D, Pseudocentrotus depressus, QAnthocidaris crassispina, $\square$, Strongylocentrotus mudus, Eemicentrotus pulcherrimus.

(Fig. 4). Z. asiatica was distributed on the sandy bottom at depths of $5-20 \mathrm{~m}$ along some of the transects on the Tsugaru Channel coast. $P$. iwatensis was restricted in shallow water of 2 and $5 \mathrm{~m}$ also at transects on the Tsugaru Channel coast.

Four species of sea urchins were found: Pseudocentrotus depressus (A. Agassiz), Anthocidaris crassispina (A. Agassiz), Strongylocentrotus nudus (A. Agassiz), and Hemicentrotus pulcherrimus (A. Agassiz) (Fig. 5). S. nudus was found with high standing crop mostly in deep water of 10 and $15 \mathrm{~m}$ at transects on the Tsugaru Channel coast. $P$. deperessus was found in small amounts in water of 2-20 m at some transects on the Japan Sea coast. $A$. crassispina and $H$. pulcherrimus were found in small amounts restrictedly in

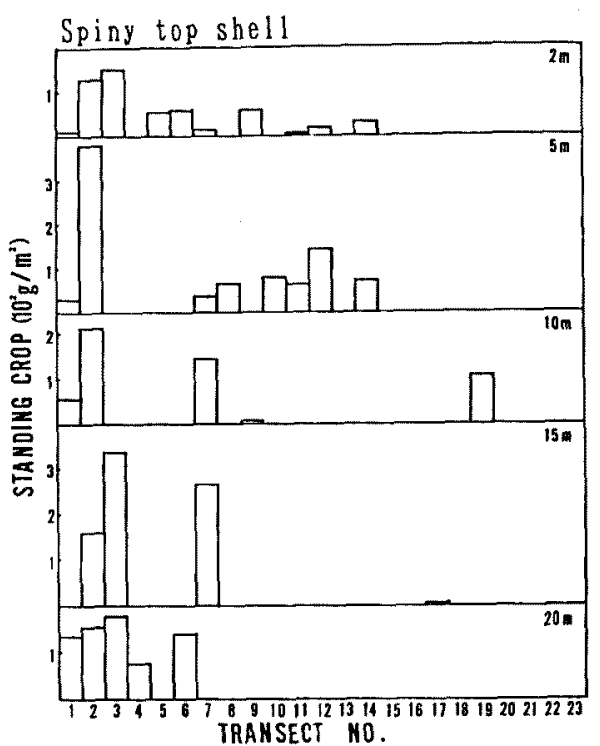

Fig. 6. Standing crops of the spiny top shell, Batillus cornutus, at different depths.

shallow water of 2 and $5 \mathrm{~m}$ on both of the coasts.

The spiny top shell, Batillus cornutus, was found in shallow to deep depths at mostly transects on the Japan Sea coast. Its standing crop was especially high at transects 1-3. At transects 8-14 on the Tsugaru Channel coast, this species was found mostly in shallow water of 2 and $5 \mathrm{~m}$ (Fig. 6).

\section{Discussion}

Vertical distributions of the standing crop of seaweeds in the present coastal waters are classiaed as follows: (1) Distribution from shallow to deep water restricted to the Japan Sea coast (Sargassum macrocarpum); (2) Distribution different between the Japan Sea coast and the Tugaru Channel coast, being found mostly in 
water from 5 to $20 \mathrm{~m}$ on the former coast and restricted mostly in shallow water on the latter coast (Ecklonia stolonifera and Myagropsis myagroides); (3) Distribution restricted mostly to the Tsugaru Channel coast with relatively high standing crop from shallow to deep water (Laminaria japonica. Sargassum micracanthum, and $S$. confusum); (4) Distribution restricted in deep water on the Tsugaru Channel coast (Kjellmaniella crassifolia and Sargassum horneri); (5) Distribution from shallow to deep water both on the Japan Sea coast and on the Tsugaru Channel coast (Sargassum siliquastrum).

In consideration of the distribution patterns (1), (2), and (3), Tappi Point seems to be the border between the Japan Sea coast and the Tsugaru Channel coast, with different environmental conditions for the distribution of seaweeds. The same conclusion was derived on Tappi Point in our previous report. ${ }^{12)}$

Kjellmaniella crassifolia was observed in deep water of $10-20 \mathrm{~m}$ on other coasts of Aomori Prefecture except at Oh'hata, ${ }^{8,12)}$ although this species was reported to occur in shallow water of 5-8 $\mathrm{m}$ on the coast of Minamikayabe in southern Hokkaido. ${ }^{13)}$ Sargassum horneri was also characteristically found in deep water on all the coasts of Aomori Prefecture, even though this species was reported to occur in shallow water along the coasts of central and southern Japan. ${ }^{14,15)}$

The pattern of vertical distribution of the spiny top shell was very similar to that of Ecklonia stolonifera on the Tsugaru Channel coast. The pattern of vertical distribution of sea urcihs, especially of Strongylocentrotus nudus, was very similar to that of Laminaria japonica also on the Tsugaru Channel coast. These results suggest that the two species of seaweeds have an affinity with the animals in respect to food or habitat. At Ohma, the central part of the Tsugaru Channel coast, the spiny top shell was usually found in the Ecklonia stolonifera community but not in the Laminaria japonica community (Notoya, unpublished).

Thus, according to the vertical distribution of seaweeds, the spiny top shell and sea urchins, it is concluded that the coast around the Tappi Point can be divided into two regions with different environmental conditions.

\section{Acknowledgements}

The authors are thankful to Mr. M. Asuke and Mr. S. Kirihara at Aquaculture Center, Aomori Prefecture for their contribution to this study in the field work.

\section{References}

1) K. Watanabe: Hokkaido shuhen no kaikyo oyobi kisho no tokushoku. Bull. Coastal Oceanogr., 3, 23-30 (1964).

2) K. Watanabe: Summary of drift ice in the Okhtsk Sea. Proc. Intl. Conf. Low Temp. Sci, 1. Physics of Snow and Ice., 667-686 (1967).

3) K. Okamura: Marine algae of Mutsu Bay and adjacent waters. Sci. Rep. Tohaku Inp. Univ., 3, 1-17 (1927).

4) Y. Yamada: Marine algae of Mutus Bay and adjacent water. II. Sci. Rep. Tohoku Imp. Univ., 3, 497-534 (1938).

5) M. Takamatsu: Marine algae from Tsugaru Strait, northeastern Honshu, Japan. Saito Ho-onkai Mus. Res. Bull. 17, 2 I-83 (1938).

6) K. Tanaka, K. Konno, S. Saito, and M. Kawai: Marine algae in the vicinity of the Fukaura Marine Biological Laboratory. Rep. Fukaura Mar, Biol. Lab., 1, 23-27 (1969)

7) K. Kato and T. Kato: A list of the marine algae from the coast Akita Prefecture and southern part of Aomori Prefecture. Bull, Jap. Soc. Phycol., 11, 62-70 (1963).

8) Y. Nanao; On the marine algae of Mutsu Bay. J. Aamoriken Biol, Soc., 13, 12-20 (1972).

9) M. Notoya and M. Asuke: Distribution of Laminariales plants along the coast of Aomori Prefecture. Sci. Rep. Aquacult. Center Aomori Pref., 3, 15-18 (1984).

10) S. Kawashima: Kombu cultivation in Japan for human foodstuff. Jap. J. Phycol., 32, 379-394 (1984).

11) M. Notoya: Vertical distribution of several species of seaweeds along the coasts of Tappi-Fujishima in Aomori Prefecture. Proc. 53rd Ann. Meating Bot. Soc. Japan, 207 (1988),

12) M. Notoya and $Y$. Aruga: Vertical distribution of several species of macroalgae (Phaeophyta) along the coasts of Aomori Prefecture, Japan. Korean J. Phycol, 4, 165-170 (1989).

13) H. Yamamoto: Monthly changes in the occurrence and growth of Kjellmaniella crassifolia Miyabe. Bull. Fac. Fish. Hokkaido Uniy., 37, 165-170 (1986).

14) I. Urmezaki: Ecological studies of Sargassum homeri(Turner) C. Agradh in Obama Bay, Japan Sea. Nippon Suisan Gakkaishi, 50, 1193-1200 (1984).

15) T. Terawaki: Growth and maturation of Sargassum horneri in Odawa Bay, Miura Peninshula. Aquiculture, 3, 177-181 (1986). 